Mr. F. J. Evans also refers to the vast amount of animal life, and mentions the quantities of sharks and alligators which abound in and about Greytown Harbour. I can fully corroborate this, although I believe that what Mr. Evans terms alligators are really crocodiles (Molinia Americana), I should be glad to have certain information on this point: when not actually visible, their proximity is made evident by a powerful odour of musk. The most notable, however, of the denizens of these waters, besides the turtle, is the Atlantic manatee, which Columbus mistook for a mermaid, and which Agassiz terms the modern representative of the Dinotherium. The Mosquito Indians on the Indian, Rama, and Blewfields rivers are great adepts at harpooning this paradoxical mammal, and its flesh salted is a staple article of food all along these coasts, being not unlike to ship's pork.

Southsea, April 28

S. P. Oliver

P.S.-When at anchor off Greytown, also in the Danube steamer, during the night of February 15, 1867, (moon eleven days old) there was no vibration or noise perceived, but then there was a tremendous swell breaking with high surf on the bar, and the vessel rolling heavily. It would be interesting to overhaul the logs of the Royal Mail Company's vessels which have been at Greytown, in order to discover the periods of these vibrations, but $I$ am afraid that no observations have been recorded in their books.

\section{Mechanical Equivalence of Heat}

You will see from the proceedings of the Literary and Philosophical Society at Manchester, that, since the discussion there, Dr. Joule has definitely abandoned the reasonings in his famous paper on the mechanical force of electro-magnetism, steam, and horses. I have now had time to test the facts and experiments of this new theory, and find it, as $I$ hope soon to show in detail, as untenable as his former one. Indeed, I am sure that the mechanical equivalence of heat must soon be generally abandoned as inconsistent with facts. You will see that the April number of the "Review of Popular Science," has definitely pronounced a decision in my favour; and I am sure you will soon be convinced yourself that your own first reviewer of my article in the Qucrterly Fournal of Science was more reasonable than your second.

H. HIGHTON

\section{Aurora by Daylight}

AN additional well-authenticated instance of this very rare but indisputable phenomenon, may, perhaps, be thought worthy of insertion.

In the Transactions of the Royal Irish Academy for 1788 (embodied in "Memoirs of Science and the Arts," I 798), is "An Account of an Aurora Borealis seen in full Sunshine, by the Rev. Henry Ussher, D.D." which opens in the ensuing manner :-

"The following phenomenon being very uncommon, if not entirely new, I think it worth communicating to the Academy, principally with a view to learn whether any other person has observed a similar one at any time:-

" 'On Saturday night, May 24, I 788 , there was a very bright aurora borealis, the coruscating rays of which united, as usual, in the pole of the dipping needle. I have always observed that an aurora borealis renders the stars remarkably unsteady in the telescope. The next morning, about eleven, finding the stars flutter nuch, I examined the state of the sky, and saw whitish rays ascending from every part of the horizon, all tending to the pole of the dipping needle, where at their union they formed a small thin and white canopy, similar to the luminous one exhibited by an aurora at night. These rays coruscated or shivered from the horizon to their point of union. These effects were distinctly seen by three different people, and their point of union marked separately by each of them."

\section{T. W. WEBB}

\section{The Coronal Rifts}

THE enclosed extract of a letter from Captain Tupman, who observed the Eclipse of December last throngh the finder of Prof. Harlness's telescope at Syracuse, may interest some of your readers :-

"It is a singluar feature in all the photographs that the 'rifts' are so wide and distinct. They are actinic rifts. As seen in the telescope simply the corona had no such rifts. I watched it during the whole IO5 seconds; such a feature would, of course, have struck me instantly. I actually pointed Prof. Harkness's spectroscope $i n$ the rifts as being bright parts of the corona!"

A. C. RANYARD

\section{The Name "Britain"}

As "C. L. N. F." has in your last well answered the letter of "A. R. H.," I have now only to reply to Mr. Hyde Clarke's letter, in which he says I should find it difficult in my derivation of "Britannia" and "tin" "to explain on the same basis the conformable names" of the countries and rivers which he mentions, inasmuch as " these names are not explainable in Phoenician, because they were given long before the Phonicians entered on the stage of history."

His paper read before the Anthropological Institute I have not seen, but as "the learned" Bochart and other authors have considered the name "Britain" to have been derived from the tin which the Phœnicians exported from Cornwall more than 3,000 years ago (Num. xxxi. 22), and as no one will venture to say that "tin" was not then the name of this metal in the most ancient Cornish as well as in the Phœenician language, from which it proceeded, I do not think I can fairly be called upon to go into the "difficult" task suggested by Mr. Clarke.

The original name of our island I have imagined to be Bretir ("Tin Mount"), that being at first exclusively the name of the mount from which the Cornish tin was exported by the Phœnicians, and it is highly probable that the same name was afterwards given by these ancient traders to the entire island, ot which the mount was only a part, for it was Britain that gave them nearly all their tin, and its most beautiful natural object kuown to them was St. Michael's Mount.

There being other islands close to Britain, the Romans gave the name Britanniz indiscriminately to them all. When they spoke of Britain as dissociated from its contiguous islands, they called it either Britannia or Insula Britannica, which is synony-

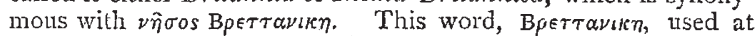
first adjectively by the Greeks, had in the time of Diodorus Siculus become a substantive, so that he uses it as such when describing the daily insulated port or mount called sometimes Iktin (Tin Port), and sometimes Bretin (Tin Mount), adjacent to B $\rho \in \tau \tau a \nu l k \eta$, to which port or mount at low water the tin was carried from the mainland for sale and exportation. The follow-

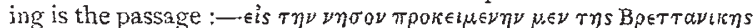

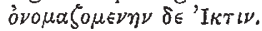

Plymouth, May 6

RICHARD EDMONDS

** We cannot print any more letters on this subject. -ED.

\section{The Sensation of Colour}

Prof. Clerk MaXweli, in his valuable paper on Colour in NATURE (vol. iv. p. I3) commits himself to the opinion that there must be three distinct sets of retinal nerves, one for each of the three primary sensarions of colour. It is obvious that demonstrative proof or disproof of this is unattainable : we can only reason analogically. The analogy of the ear is in favour of such an opinion, so far as it goes ; for there appears to be proof, or probability almost amounting to proof, that sounds of different pitch are conveyed to the brain by different nerves. But the ear resembles the other organs of sense less than they resemble each other; and there is surely no reason for thinking that there are distinct nerves of smell for every distinct kind of smell, or distinct nerves of taste for every distinct kind of taste. Nor I believe is there the slightest proof of nerves for the sensation of heat distinct from those of touch.

Old Forge, Dunmurry, Co. Antrim, May 8

\section{JOSEPH JOHN MURPHY}

P.S.-I am not now at home. I intend to write in reply to Mr. Laughton's important letter on the Prevalence of West Winils, when I am at home and have the file of NATURE and other authorities to refer to.

\section{The Cave-Lion in the Peat of Holderness}

WHILST engaged in the task of rearranging this Museum, I have been impressed with the value of two specimens in the Palrentological collection.

One is labelled "No. 7, Felis-metatarsal inner (Right side)," 